\title{
PERAMALAN EKSPOR NONMIGAS DENGAN VARIASI \\ KALENDER ISLAM MENGGUNAKAN X-13-ARIMA-SEATS \\ (Studi Kasus: Ekspor Nonmigas Periode Januari 2013 sampai Desember 2017)
}

\author{
Eka Lestari ${ }^{1}$, Tatik Widiharih $^{2}$, Rita Rahmawati ${ }^{3}$ \\ 1,2,3 Departemen Statistika, Fakultas Sains dan Matematika, Universitas Diponegoro \\ e-mail : ekalelestari@gmail.com
}

\begin{abstract}
Non-oil and gas exports are one of the largest foreign exchange earners for Indonesia. Non-oil and gas exports always experience a decline in the month of Eid Al-Fitr due to delays in the delivery of export goods because the loading and unloading of goods at the port is reduced during Eid Al-Fitr. The shift of the Eid AlFitr month on the data will form a pattern or season with an unequal period called the moving holiday effect. The time series forecasting method that usually used the ARIMA method. Because the ARIMA method only suitable for time series data with the same seasonal period and can't handle the moving holiday effect, the X13-ARIMA-SEATS method used two steps. First, regARIMA modeling is a linear regression between time series data and the weight of Eid Al-Fitr and the residuals follow the ARIMA process. The weighting is based on three conditions, namely pre_holiday, post_holiday, and multiple. Second, X-12-ARIMA decomposition method for seasonal adjustments that produces trend-cycle components, seasonal, and irregular. Based on the analysis carried out on the monthly non-oil and gas export data for the period January 2013 to December 2017, the X-13-ARIMA-SEATS $(1,1,0)$ model was obtained in the post_holiday condition as the best model. The forecasting results in 2018 show the largest decline in non-oil and gas exports in June 2018 which coincided with the Eid Al-Fitr holiday. MAPE value of $10.90 \%$ is obtained which shows that the forecasting ability is good.
\end{abstract}

Keywords: time series, non-oil and gas, X-13-ARIMA-SEATS, moving holiday

\section{PENDAHULUAN}

Menurut Bank Indonesia (2009), sektor nonmigas merupakan sektor yang memberikan sumbangan devisa terbesar untuk Indonesia. Komoditas pada sektor nonmigas dapat dibagi menjadi dua kelompok yaitu, kelompok barang dagangan umum dan kelompok barang lainnya seperti emas nonmoneter. Sektor nonmigas pada kelompok barang dagangan umum dapat dirinci menjadi sektor pertanian, sektor industri, sektor pertambangan dan sektor barang dagangan lainnya (barang seni, barang lainnya yang tidak dirinci secara spesifik dan barang yang diperoleh di pelabuhan oleh sarana pengangkut). Perincian ini dilakukan berdasar pada Harmonized Commodity Description and Coding System (HS).

Menurut Siaran Pers Kementerian Perdagangan Republik Indonesia (2017), pada pertengahan tahun 2017 ekspor nonmigas mengalami penurunan sebesar 20,7\%, dari US\$ 13,1 pada Mei 2017 menjadi US\$ 10,3 pada bulan Juni 2017. Menurut Drs. Enggartiasto Lukita selaku Menteri Perdagangan Indonesia saat ini, menurunnya ekspor selama Juni 2017 diperkirakan akibat tertundanya pengiriman barang ekspor yang disebabkan oleh aktivitas bongkar muat barang di pelabuhan berkurang selama bulan puasa dan Idul Fitri yang jatuh pada tanggal 25-26 Juni 2017.

Hari raya Idul Fitri ditetapkan berdasarkan kalender Islam, hal ini akan menyebabkan adanya pergeseran tanggal disetiap tahunnya pada kalender Masehi. Menurut Shuja et al. (2007), tanggal perayaan hari raya Idul Fitri yang berpindah dari tahun ke tahun ini dikenal sebagai "moving holiday effect". Pergeseran waktu ini berpengaruh pada peramalan data time series musiman, karena model Autoregressive Integrated Moving Average (ARIMA) musiman hanya sesuai untuk musiman dengan periode yang sama, hal ini mengakibatkan peramalan yang kurang tepat. 
Sarhani and Afia (2014) mengemukakan bahwa Biro Sensus Amerika Serikat dan Bank Spanyol mengembangkan X-13-ARIMA-SEATS yang merupakan gabungan antara metode regARIMA dengan metode seasonal adjustment. Metode regARIMA bertujuan untuk menghilangkan moving holiday effect. Pada metode regARIMA untuk tiap bulannya diberi bobot mengikuti pembobotan yang dilakukan oleh Bell and Hillmer (1983). Terdapat dua metode seasonal adjustment yang disediakan yaitu, metode dekomposisi X12-ARIMA dan TRAMO/SEATS (Time series Regression with ARIMA noise, Missing value, and Outliers/Signal Extraction in ARIMA Time Series). Proses seasonal adjustment bertujuan untuk membantu meningkatkan ketepatan peramalan dan membantu mengidentifikasi pola data time series secara lebih baik.

Berdasarkan uraian tersebut, penulis mengambil topik mengenai "Peramalan Ekspor Nonmigas dengan Variasi Kalender Islam Menggunakan X-13-ARIMA-SEATS (Studi Kasus Ekspor Nonmigas Periode Januari 2013 sampai Desember 2017)". Pemberian bobot dilakukan dengan memperhatikan tiga macam kondisi, yaitu lonjakan data terjadi sebelum perayaan yang disebut pre_holiday, sesudah perayaan yang disebut post_holiday dan selama perayaan yang disebut kondisi multiple.

\section{TINJAUAN PUSTAKA}

\subsection{Matriks Pembobot}

Menurut Bell and Hillmer (1983), matriks pembobot adalah matriks yang elemennya merupakan bobot efek kalender. Dengan mengasumsikan jumlah total hari yang berpengaruh pada perayaan adalah $\tau$ hari yang bisa terjadi pada satu bulan atau dua bulan dalam satu tahunnya, maka nilai bobot pada bulan ke-i tahun ke- $j$ untuk hari yang berpengaruh pada perayaan yang terjadi pada satu bulan dalam satu tahunnya, yaitu sebagai berikut:

$$
w_{i, j}=\left\{\begin{array}{c}
1, \text { jika terdapat hari yang berpengaruh pada perayaan } \\
0, \text { jika tidak terdapat hari yang berpengaruh pada perayaan }
\end{array}\right.
$$

nilai bobot pada bulan ke- $i$ tahun ke- $j$ untuk hari yang berpengaruh pada perayaan yang terjadi pada dua bulan dalam satu tahunnya, yaitu sebagai berikut:

$$
w_{i, j}=\left\{\begin{array}{c}
\frac{\tau_{1}}{\tau}, \text { untuk bulan ke-1 } \\
\frac{\tau_{2}}{\tau}, \text { untuk bulan ke-2 } \\
0, \text { yang lainnya }
\end{array}\right.
$$

Pada tahap ini dihasilkan matriks pembobot $\boldsymbol{W}^{*}$ dengan elemen dinotasikan dengan $w_{t}, \mathrm{t}=1,2,3, \ldots, \mathrm{n}$ dengan $\mathrm{n}=12 \times \mathrm{y}$, maka diperoleh:

$$
\boldsymbol{W}^{*}=\left[\begin{array}{c}
w_{1} \\
w_{2} \\
w_{3} \\
\vdots \\
w_{n}
\end{array}\right]
$$

\subsection{Regresi Linier}

Menurut Sembiring (2003), persamaan regresi linier antara variabel dependen $(\boldsymbol{Z})$ terhadap variabel independen $\left(\boldsymbol{W}^{*}\right)$ tanpa konstan dengan jumlah data sebanyak $\mathrm{n}$ dalam bentuk matriks dituliskan sebagai berikut:

dimana:

$$
\boldsymbol{Z}=\boldsymbol{W}^{*} \beta+\boldsymbol{N}
$$




$$
\boldsymbol{Z}=\left[\begin{array}{c}
Z_{1} \\
Z_{2} \\
Z_{3} \\
\vdots \\
Z_{n}
\end{array}\right] \quad \boldsymbol{W}^{*}=\left[\begin{array}{c}
w_{1} \\
w_{2} \\
w_{3} \\
\vdots \\
w_{n}
\end{array}\right] \quad \boldsymbol{N}=\left[\begin{array}{c}
N_{1} \\
N_{2} \\
N_{3} \\
\vdots \\
N_{n}
\end{array}\right]
$$

Estimasi parameter $\beta$ menggunakan metode kuadrat terkecil dengan meminimumkan jumlah kuadrat galatnya. Jika $\hat{\beta}$ adalah estimasi dari $\beta$, maka diperoleh:

$$
\hat{\beta}=\left(\boldsymbol{W}^{* T} \boldsymbol{W}^{*}\right)^{-1} \boldsymbol{W}^{* T} \boldsymbol{Z}
$$

\subsection{Stasioneritas dan Penanganannya}

Menurut Wei (2006), kondisi stasioner merupakan kondisi ketika proses suatu data time series tidak berubah seiring dengan adanya perubahan waktu. Proses tersebut disebut stasioner jika mean dan variansinya konstan untuk setiap titik $t$ dan kovarian yang konstan untuk setiap selang waktu $k$. Terdapat dua macam stasioneritas yaitu, stasioneritas dalam varian dan stasioneritas dalam mean. Data yang stasioner dalam varian memiliki nilai $\lambda=1$ pada uji Box-Cox. Jika data time series tidak stasioner pada variannya, maka dapat dilakukan transformasi stabilitas varian, seperti transformasi Box-Cox dengan rumus sebagai berikut:

$$
T\left(N_{t}\right)=\left\{\begin{array}{c}
N_{t}^{\lambda}, \lambda \neq 0 \\
\ln \left(N_{t}\right), \lambda=0
\end{array}\right.
$$

Stasioneritas dalam mean di uji mengggunakan uji Dickey-Fuller dengan hipotesis sebagai berikut:

Hipotesis: $\quad \mathrm{H}_{0}:\left|\phi_{1}\right|=1$ (Proses tidak stasioner)

Taraf signifikansi: $\alpha$

$$
\mathrm{H}_{1}:\left|\phi_{1}\right|<1 \text { (Proses stasioner) }
$$

Statistik uji: $\quad T=\frac{\widehat{\phi}_{1}-1}{\operatorname{SE}\left(\widehat{\phi}_{1}\right)}$

Kriteria penolakan: menolak $\mathrm{H}_{0}$ jika $T>D F_{n ; \alpha}$ atau $p_{\text {value }}<\alpha$.

Menurut Makridakis et al. (1995), jika data tidak stasioner dalam mean, maka penanganannya menggunakan metode pembedaan (differencing).

\subsection{Fungsi Autokorelasi (ACF) dan Fungsi Autokorelasi Parsial (PACF)}

Menurut Wei (2006), suatu proses runtun waktu $N_{t}$ yang stasioner terdapat nilai mean $E\left(N_{t}\right)=\mu$, varian $\operatorname{Var}\left(N_{t}\right)=E\left(N_{t}-\mu\right)^{2}=\sigma^{2}$ yang mempunyai nilai-nilai yang konstan dan kovarian $\operatorname{Cov}\left(N_{t}, N_{t+k}\right)$. Dari sini dapat ditulis kovarian antara $N_{t}$ dan $N_{t+k}$ dan korelasi antara $Z_{t}$ dan $Z_{t+k}$ adalah sebagai berikut:

$$
\begin{aligned}
& \gamma_{k}=\operatorname{Cov}\left(N_{t}, N_{t+k}\right)=E\left(N_{t}-\mu\right)\left(N_{t+k}-\mu\right) \\
& \rho_{k}=\frac{\operatorname{Cov}\left(N_{t}, N_{t+k}\right)}{\sqrt{\operatorname{Var}\left(N_{t}\right)} \sqrt{\operatorname{Var}\left(N_{t+k}\right)}}=\frac{\gamma_{k}}{\gamma_{0}}
\end{aligned}
$$

Menurut Wei (2006), untuk proses yang stasioner, memiliki sifat sebagai berikut:

1. $\gamma_{0}=\operatorname{Var}\left(N_{t}\right)$, dimana $\rho_{0}=1$

2. $\left|\gamma_{k}\right| \leq \gamma_{0}$, dimana $\left|\rho_{k}\right| \leq 1$

3. $\gamma_{k}=\gamma_{-k}$, dimana $\rho_{k}=\rho_{-k}$

PACF dapat dinyatakan sebagai berikut:

$$
\phi_{k k}=\frac{\left|\boldsymbol{\rho}_{k}{ }^{*}\right|}{\left|\boldsymbol{\rho}_{k}\right|}
$$


dimana: $\quad \boldsymbol{\rho}_{k}=\left[\begin{array}{cccccc}1 & \rho_{1} & \rho_{2} & \rho_{3} & \cdots & \rho_{k-1} \\ \rho_{1} & 1 & \rho_{1} & \rho_{2} & \cdots & \rho_{k-2} \\ \rho_{2} & \rho_{1} & 1 & \rho_{1} & \cdots & \rho_{k-3} \\ \rho_{3} & \rho_{2} & \rho_{1} & 1 & \cdots & \rho_{k-4} \\ \vdots & \vdots & \vdots & \vdots & \ddots & \vdots \\ \rho_{k-1} & \rho_{k-2} & \rho_{k-3} & \rho_{k-4} & \cdots & 1\end{array}\right]$

Dengan $\boldsymbol{\rho}_{k}{ }^{*}$ adalah matriks autokorelasi $k \times k$ dengan kolom terakhir diganti dengan $\left[\begin{array}{c}\rho_{1} \\ \rho_{2} \\ \vdots \\ \rho_{k}\end{array}\right]$.

\subsection{Model ARIMA (Autoregressive Integrated Moving Average)}

\subsubsection{Model ARIMA Non Musiman}

Menurut Wei (2006), model ARIMA(p,d,q) secara umum adalah:

$\phi_{p}(B)(1-B)^{d} N_{t}=\theta_{q}(B) a_{t}$

\subsubsection{Model ARIMA Musiman}

Menurut Wei (2006), ARIMA(p,d,q)(P,D,Q $)^{\mathrm{S}}$ secara umum adalah:

$\Phi_{P}\left(B^{S}\right) \phi_{p}(B)(1-B)^{d}\left(1-B^{S}\right)^{D} N_{t}=\theta_{q}(B) \Theta_{Q}\left(B^{S}\right) a_{t}$

\subsection{Uji Signifikansi Parameter Model}

Hipotesis:

$\mathrm{H}_{0}: \delta=0$ (parameter tidak berpengaruh signifikan terhadap respon yang diamati)

$\mathrm{H}_{1}: \delta \neq 0$ (parameter berpengaruh signifikan terhadap respon yang diamati)

Taraf signifikansi: $\alpha$

Statistik uji: $t_{\text {hitung }}=\frac{\widehat{\delta}_{1}}{\operatorname{se}\left(\widehat{\delta}_{1}\right)}$

Kriteria uji: Menolak $\mathrm{H}_{0}$ jika $\left|t_{\text {hitung }}\right|>t_{\left(\frac{\alpha}{2}, n-s\right)}$ atau $p_{\text {value }}<\alpha$

\subsection{Uji Asumsi Model}

\subsubsection{Uji White Noise Residual Model}

Hipotesis:

$\mathrm{H}_{0}: \rho_{1}=\rho_{2}=\cdots=\rho_{m}=0$ (tidak ada korelasi residual antar lag)

$\mathrm{H}_{1}$ :Paling sedikit ada satu $\rho_{k} \neq 0$ dengan $k=1,2, \ldots, m$ (ada korelasi residual antar lag) Taraf Signifikansi: $\alpha$

Statistik uji: $Q_{\text {hitung }}=n(n+2) \sum_{k=1}^{m} \frac{\hat{\rho}_{k}{ }^{2}}{(n-k)}$

Kriteria uji: Menolak $\mathrm{H}_{0}$ jika $Q_{\text {hitung }}>\chi_{(\alpha ; m-s)}^{2}$ atau $p_{\text {value }}<\alpha$

\subsubsection{Uji Normalitas Residual}

Hipotesis:

$\mathrm{H}_{0}$ : Residual berdistribusi normal

$\mathrm{H}_{1}$ : Residual tidak berdistribusi normal

Taraf Signifikansi: $\alpha$

Statistik uji: $J B=\frac{n}{6}\left(S^{2}+\frac{(K-3)^{2}}{4}\right) \quad S=\frac{\frac{1}{n} \sum_{t=1}^{n}\left(a_{t}-\bar{a}\right)^{3}}{\left(\frac{1}{n} \sum_{t=1}^{n}\left(a_{t}-\bar{a}^{2}\right)\right)^{3 / 2}} \quad K=\frac{\frac{1}{n} \sum_{t=1}^{n}\left(a_{t}-\bar{a}\right)^{4}}{\left(\frac{1}{n} \sum_{t=1}^{n}\left(a_{t}-\bar{a}\right)^{2}\right)^{2}}$

Kriteria uji: Menolak $\mathrm{H}_{0}$ jika $J B<\chi_{\alpha, 2}^{2}$ atau $p_{\text {value }}<\alpha$. 


\subsubsection{Uji Homoskedastisitas Residual}

Hipotesis:

$\mathrm{H}_{0}: a_{1}=a_{2}=\cdots=a_{m}=0$ (tidak ada efek ARCH dalam residual sampai lag ke- $m$ )

$\mathrm{H}_{1}$ : paling sedikit ada satu $a_{i} \neq 0, i=1,2, \ldots, m$ (ada efek ARCH dalam residual sampai lag ke- $m$ )

Taraf Signifikansi: $\alpha$

Statistik Uji: $\quad L M=N R^{2} \quad R^{2}=\frac{J K R}{J K T}=\frac{\sum_{t=1}^{m}\left(\hat{a}_{t}^{2}-\bar{a}_{t}^{2}\right)^{2}}{\sum_{t=1}^{m}\left(a_{t}^{2}-\bar{a}_{t}^{2}\right)^{2}}$

Kriteria Uji: Menolak $\mathrm{H}_{0}$ jika nilai statistik uji $L M>\chi_{\alpha, m}^{2}$ atau jika $p_{\text {value }}<\alpha$.

\subsection{Pemilihan Model Terbaik}

Setelah terpilih model yang memenuhi pengujian diagnostik maka dilakukan pemilihan model terbaik dengan kriteria model memenuhi prinsip parsimony atau prinsip kesederhanaan dan model memiliki nilai AIC yang kecil, dengan rumus sebagai berikut:

$$
A I C=N \log \text { likelihood }+2 s
$$

\subsection{RegARIMA}

Menurut Lin and Liu (2002), model regARIMA merupakan salah satu bentuk model variasi kalender yang dapat digunakan untuk meramalkan data berdasarkan pola musiman dengan panjang periode yang bervariasi. Menurut Bell and Hillmer (1983), data time series $Z_{t}$ yang mengandung efek variasi kalender, dituliskan dalam persamaan berikut:

$$
Z_{t}=f\left(X_{t} ; \xi\right)+N_{t}
$$

dimana $N_{t}=\frac{\theta_{q}(B) \Theta_{Q}\left(B^{S}\right)}{\phi_{P}(B) \Phi_{P}\left(B^{S}\right)(1-B)^{d}\left(1-B^{S}\right)^{D}} \alpha_{t}$

Sehingga diperoleh model regARIMA sebagai berikut:

$$
\Phi_{P}\left(B^{s}\right) \phi_{p}(B)(1-B)^{d}\left(1-B^{s}\right)^{D}\left(Z_{t}-\hat{f}\left(X_{t} ; \xi\right)\right)=\theta_{q}(B) \Theta_{Q}\left(B^{s}\right) e_{t}
$$

\subsection{Dekomposisi X-12-ARIMA}

Menurut National Statistics (2007), metode dekomposisi X-12-ARIMA dikembangkan oleh David F. Findley dan kawan-kawan dari Biro Sensus Amerika Serikat pada tahun 1995 merupakan salah satu metode yang digunakan untuk mendekomposisi faktor-faktor yang ada pada pola data. Metode ini terdiri dari perluasan data time series yang diberikan oleh forecasting $N_{t}$ dan backcasting $N_{t}$ dari model regARIMA pada Persamaan 19, data ini dinotasikan dengan $O_{t}{ }^{(1)}$. Selanjutnya digunakan metode dekomposisi X-12-ARIMA untuk data $O_{t}{ }^{(1)}$ dengan 3 tahap dan diasumsikan model dekomposisi yang digunakan adalah model multiplikatif dengan langkah-langkah berikut:

\section{Tahap 1. Estimasi Awal}

a. Estimasi komponen trend-siklus pertama.

$$
C T_{t}^{(1)}=M A_{2 \times 12}\left(O_{t}{ }^{(1)}\right)
$$

b. Estimasi komponen musiman-irregular.

$$
S I_{t}^{(1)}=O_{t}{ }^{(1)} / C T_{t}{ }^{(1)}
$$

c. Estimasi komponen musiman awal

$$
\begin{aligned}
S_{t}{ }^{(0)} & =M A_{3 \times 3}\left(S I_{t}{ }^{(1)}\right) \\
S_{t}{ }^{(1)} & =\frac{(\text { Jumlah Bulan } \times 100)}{\sum S_{t}{ }^{(0)}} \times S_{t}{ }^{(0)} \\
I_{t}{ }^{(1)} & =S I_{t}{ }^{(1)} / S_{t}{ }^{(1)}
\end{aligned}
$$$$
D_{t}=\frac{\left|I_{t}^{(1)}-u_{1}\right|}{\sigma}
$$ 


$$
W_{t}=\left\{\begin{array}{cl}
0, & D_{t}>S_{u} \\
1, & D_{t}<S_{l} \\
\frac{s_{u}-D_{t}}{S_{u}-S_{l}}, & S_{l}<D_{t}<S_{u}
\end{array}\right.
$$

Jika $W_{t} \neq 1$, maka $S I_{t}^{(1)}$ sebagai nilai ekstrim yang harus diganti. Pergantian nilai ekstrim dilakukan pada masing-masing bulan secara terpisah (Monsell, 1984) dengan cara berikut:

$$
\begin{aligned}
& S I_{t}{ }^{(2)}=\frac{W_{e} S I_{e}{ }^{(1)}+\sum_{i=1}^{k} S I_{i}{ }^{(1)}}{k+1} \\
& S_{t}{ }^{(2)}=M A_{3 \times 3}\left(S I_{t}{ }^{(2)}\right)
\end{aligned}
$$

d. Estimasi komponen musiman

$$
S_{t}{ }^{(3)}=S_{t}{ }^{(2)} / M A_{2 \times 12}\left(S_{t}{ }^{(2)}\right)
$$

e. Penyesuaian musiman awal.

$$
S A_{t}{ }^{(1)}=O_{t}{ }^{(1)} / S_{t}{ }^{(3)}
$$

Tahap 2. Estimasi Akhir dari Komponen Musiman dan Data Penyesuaian Musiman

a. Estimasi komponen trend-siklus Henderson.

$$
C T_{t}{ }^{(2)}=H_{13}\left(S A_{t}{ }^{(1)}\right)
$$

b. Estimasi komponen musiman-irregular.

$S I_{t}{ }^{(3)}=O_{t}{ }^{(1)} / C T_{t}{ }^{(2)}$

c. Estimasi komponen musiman.

$$
\begin{array}{rrr}
S_{t}{ }^{(4)} & =M A_{3 \times 5}\left(S I_{t}{ }^{(3)}\right) & I_{t}{ }^{(2)}=S I_{t}{ }^{(3)} / S_{t}{ }^{(5)} \\
S_{t}{ }^{(5)} & =\frac{(\text { Jumlah Bulan } \times 100)}{\sum S_{t}{ }^{(4)}} \times S_{t}{ }^{(4)} & D_{t}=\frac{\left|I_{t}{ }^{(2)}-u_{2}\right|}{\sigma}
\end{array}
$$

Jika $W_{t} \neq 1$, maka $S I_{t}{ }^{(3)}$ sebagai nilai ekstrim yang harus diganti. Pergantian nilai ekstrim dilakukan pada masing-masing bulan secara terpisah (Monsell, 1984):

$$
\begin{aligned}
S I_{t}{ }^{(4)} & =\frac{W_{e} S I_{e}{ }^{(3)}+\sum_{i=1}^{k} S I_{i}{ }^{(3)}}{k+1} \\
S_{t}{ }^{(6)} & =M A_{3 \times 5}\left(S I_{t}{ }^{(4)}\right)
\end{aligned}
$$

d. Estimasi komponen musiman yang sudah dibuat normal.

$$
S_{t}{ }^{(7)}=S_{t}{ }^{(6)} / M A_{2 \times 12}\left(S_{t}{ }^{(6)}\right)
$$

e. Penyesuaian musiman akhir.

$$
S A_{t}{ }^{(2)}=O_{t}{ }^{(1)} / S_{t}{ }^{(7)}
$$

Tahap 3. Estimasi Akhir dari Komponen Trend-Siklus dan Irregular

a. Estimasi komponen trend-siklus. Pemilihan rata-rata bergerak Henderson untuk mengestimasi komponen trend-siklus dibuat berdasarkan nilai $\bar{I} / \bar{C} \bar{T}$.

$\frac{\bar{I}}{\bar{C} \bar{T}}=\frac{\sum_{t=1}^{n} I_{t}^{(2)}}{\sum_{t=1}^{n} C T_{t}^{(2)}}$

Rata-rata bergerak yang cocok untuk sembarang $\bar{I} / \bar{C} \bar{T}$ dijelaskan pada Tabel 1 .

Tabel 1. Pemilihan Rata-rata Bergerak Henderson

\begin{tabular}{cl}
\hline $\bar{I} / \bar{C} \bar{T}$ & \multicolumn{1}{c}{ Rata-rata bergerak yang dipilih } \\
\hline $0,00-0,99$ & Rata-rata bergerak Henderson 9-suku \\
$0,99-3,49$ & Rata-rata bergerak Henderson 13-suku \\
$\geq 3,50$ & Rata-rata bergerak Henderson 23-suku \\
\hline
\end{tabular}

Sumber: Shiskin et al. (1967).

$$
C T_{t}{ }^{(3)}=H_{n}\left(S A_{t}{ }^{(2)}\right)
$$

b. Estimasi komponen irregular.

$$
I_{t}{ }^{(3)}=S A_{t}{ }^{(2)} / C T_{t}{ }^{(3)}
$$




\subsection{Pengujian Hasil Akhir Dekomposisi}

Menurut Makridakis et al. (1995), setelah hasil akhir dekomposisi diperoleh, selanjutnya dilakukan pengujian deret data untuk menentukan apakah dekomposisi tersebut sukses atau tidak. Terdapat dua uji untuk hasil dekomposisi yang digunakan. Pertama, uji bulan yang berdekatan dengan rumus sebagai berikut:

$$
R_{t}=\frac{S A_{t}^{(2)}}{\frac{\left(S A_{t-1}{ }^{(2)}+S A_{t+1}(2)\right.}{2}}
$$

Kedua, uji Januari dengan rumus sebagai berikut:

$$
R_{\text {bulan,tahun }}=\frac{S A_{\text {bulan,tahun }}{ }^{(2)}}{S A_{\text {Januari,tahun }}{ }^{(2)}}
$$

Jika nilai rata-rata rasio berada pada interval 95\%-105\%, maka proses penyesuaian musiman cukup berhasil menghilangkan variasi musiman.

\subsection{X-13-ARIMA-SEATS}

Menurut United States Census Bureau (2018), X-13-ARIMA-SEATS merupakan versi penyempurnaan dari X-12-ARIMA yang dikembangkan oleh United States Census Bureau. Pada metode X-12-ARIMA data perluasannya dihasilkan dari model ARIMA, sedangkan pada metode X-13-ARIMA-SEATS data perluasannya dihasilkan dari model regARIMA. Penggunaan model regARIMA bertujuan untuk menghilangkan efek kalender dalam hal ini yaitu moving holiday. Terdapat dua macam dekomposisi dalam metode X13-ARIMA-SEATS, yaitu dekomposisi X-12-ARIMA dan TRAMO/SEATS yang bertujuan untuk mengestimasi faktor musiman. Secara umum proses X-13-ARIMASEATS adalah sebagai berikut:

1. Menghilangkan efek moving holiday yang terdapat dalam data $Z_{t}$ dengan menggunakan model regARIMA pada Persamaan 19.

2. Memperluas data observasi dengan backcasting dan forecasting berdasarkan model regARIMA pada Persamaan 19.

3. Mendekomposisi data perluasan pada Langkah 2 menggunakan dekomposisi X-12ARIMA dengan mengasumsikan model dekomposisi yang digunakan adalah model multiplikatif.

\subsection{PERAMALAN}

Peramalan pada beberapa bulan yang diinginkan diperoleh dari hasil kali faktor musiman yang diramalkan satu tahun ke depan dengan taksiran trend-siklus pada tahun sebelumnya menurut Makridakis et al. (1995).

$$
F_{t}=S_{t+12}{ }^{(7)} \times C T_{t}{ }^{(3)}
$$

Untuk mendapatkan nilai ramalan musiman digunakan rumus berikut (Biro Pusat Statistik Israel, 2007).

$$
S_{t+12}{ }^{(7)}=S_{t}{ }^{(7)}+\frac{S_{t}{ }^{(7)}-S_{t-12}(7)}{2}
$$

\subsection{Evaluasi Peramalan}

Makridakis et al. (1995) mengemukakan bahwa ketepatan model peramalan menjadi tolok ukur dalam memilih model yang terbaik salah satunya MAPE (Mean Absolut Percentage Error), dengan rumus sebagai berikut:

$$
M A P E=\sum_{i=1}^{n}\left|P E_{i}\right| / n \quad P E_{i}=\frac{Z_{i}-F_{i}}{Z_{i}} \times 100
$$

Semakin kecil nilai MAPE menunjukkan bahwa presentase kesalahan yang dihasilkan oleh model juga semakin kecil. 


\section{METODOLOGI PENELITIAN}

\subsection{Sumber Data}

Data yang digunakan dalam penelitian ini adalah data sekunder dari Divisi Analisis Neraca Pembayaran, Bank Indonesia. Adapun data yang diambil adalah data bulanan ekspor nonmigas yang mengacu pada nilai Free on Board (FoB) periode Januari 2013 sampai dengan Desember 2017.

\subsection{Variabel Penelitian}

Variabel yang digunakan dalam penelitian ini yaitu data ekspor nonmigas $\left(Z_{t}\right)$ dalam satuan Juta USD.

\subsection{Metode Analisis Data}

Metode analisis data akan digunakan alat bantu berupa software Microsoft Excel 2010 dan $R$ 3.4.3. Langkah-langkah yang dilakukan untuk menganalisis masalah penelitian ini sebagai berikut:

1. Menginput data ekspor nonmigas $\left(Z_{t}\right)$ periode Januari 2013 sampai dengan Desember 2017 untuk peramalan dengan metode X-13-ARIMA-SEATS.

2. Melakukan identifikasi trend, musiman, siklus, dan data ekstrim yang terdapat dalam data ekspor nonmigas dengan menggunakan plot time series.

3. Menentukan matriks pembobot $\boldsymbol{W}_{\text {pre }}^{*}, \boldsymbol{W}_{\text {multi }}^{*}$, dan $\boldsymbol{W}_{\text {post }}^{*}$.

4. Membentuk model regresi linier $Z_{t}=\beta \boldsymbol{W}_{\text {pre }}^{*}, Z_{t}=\beta \boldsymbol{W}_{\text {post }}^{*}$, dan $Z_{t}=\beta \boldsymbol{W}_{\text {multi }}^{*}$.

5. Estimasi parameter model regresi linier pada langkah (4) menggunakan OLS.

6. Melakukan uji signifikansi parameter dari model pada langkah (4). Jika parameter tidak signifikan, model tidak dipakai. Jika parameter signifikan, dilanjutkan ke langkah (7).

7. Menginput data $N_{t}$ dari masing-masing model regresi linier pada langkah (4).

8. Melakukan uji white noise $N_{t}$ pada langkah (7) dengan melihat nilai $p$-value dari uji Ljung-Box. Jika asumsi white noise dan uji normalitas residual serta uji homoskedastisitas residual terpenuhi, model regresi linier pada langkah (4) bisa digunakan untuk peramalan. Jika asumsi white noise tidak terpenuhi, dilanjutkan ke langkah (9).

9. Melakukan uji stasioneritas dalam varian data $N_{t}$ pada langkah (8) menggunakan transformasi Box-Cox. Jika $N_{t}$ tidak stasioner dalam varian, data ditransformasi Box-Cox dan kemudian diuji lagi stasioneritas dalam variannya. Jika $N_{t}$ stasioner dalam varian, dilanjutkan ke langkah (10).

10. Pengujian stasioneritas dalam mean pada data yang sudah stasioner dalam varian pada langkah (9) menggunakan uji akar unit Augmented Dickey Fuller. Jika data tidak stasioner dalam mean, dilakukan differencing dan diuji lagi stasioneritas dalam meannya. Jika data stasioner dalam mean, dilanjutkan ke langkah (11).

11. Identifikasi model regARIMA untuk data $N_{t}$ pada langkah (8) menggunakan plot ACF dan plot PACF.

12. Estimasi parameter dari model regARIMA yang terbentuk pada langkah (11).

13. Melakukan uji signifikansi parameter dari parameter yang diperoleh pada langkah (12). Jika parameter tidak signifikan, membuang variabel yang tidak signifikan lalu dimodelkan kembali tanpa variabel yang tidak signifikan dan dilakukan uji signifikansi parameter lagi. Jika parameter signifikan, dilanjutkan ke langkah (14).

14. Melakukan uji white noise residual, normalitas residual, dan homoskedastisitas residual dari model regARIMA pada langkah (13). Jika ketiga asumsinya tidak 
terpenuhi, model tidak dipakai. Jika ketiga asumsi terpenuhi, dilanjutkan ke langkah (15).

15. Pemilihan model terbaik berdasarkan nilai AIC yang terkecil pada model regARIMA pada langkah (15).

16. Membuat data perluasan yaitu data $N_{t}$ pada langkah (8) dengan menambahkan data satu tahun ke belakang yang diperoleh dengan cara backcasting dan data satu tahun ke depan yang diperoleh dengan cara forecasting data ekspor nonmigas berdasarkan model X-13-ARIMA-SEATS pada langkah (17).

17. Menghitung seasonal adjustment dengan mendekomposisi data perluasan pada langkah (18) menjadi 3 komponen yaitu trend-siklus, musiman, dan irregular. Dalam metode X-13-ARIMA-SEATS digunakan dekomposisi yang sama pada metode dekomposisi X-12-ARIMA.

18. Melakukan uji dekomposisi akhir pada hasil seasonal adjustment pada langkah (19). Jika uji dekomposisi akhir tidak terpenuhi, maka seasonal adjustment yang telah dilakukan tidak berhasil, sehingga peramalan akhir yang digunakan yaitu peramalan pada langkah (18). Jika uji dekomposisi akhir terpenuhi, dilanjutkan ke langkah (21).

19. Melakukan peramalan dan menghitung nilai MAPE.

\section{HASIL DAN PEMBAHASAN}

Dengan menggunakan software $R 3.4 .3$, pola time series dari data ekspor nonmigas $\left(Z_{t}\right)$ pada Lampiran 1 dapat dilihat pada Gambar 1. Dari plot time series pada Gambar 1 dapat diidentifikasi bahwa data ekspor nonmigas memiliki pola trend, pola musiman, dan pola non-stasioneritas.

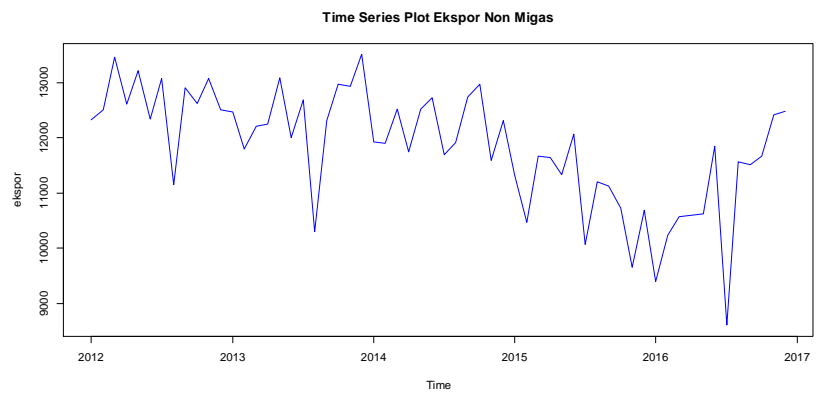

Gambar 1. Plot Time Series Data Ekspor Nonmigas

Menghitung matriks pembobotnya berdasarkan Persamaan 1 dan Persamaan 2. Pada kondisi pre_holiday, hari raya Idul Fitri mempengaruhi penurunan ekspor nonmigas selama 5 hari sebelum hari raya Idul Fitri dan pada saat hari raya Idul Fitri. Pada kondisi post_holiday, hari raya Idul Fitri mempengaruhi penurunan ekspor nonmigas selama 5 hari setelah hari raya Idul Fitri dan pada saat hari raya Idul Fitri. Pada kondisi multiple, hari raya Idul Fitri mempengaruhi penurunan ekspor nonmigas selama 2 hari sebelum hari raya Idul Fitri sampai dengan 3 hari setelah hari raya Idul Fitri. Diperoleh matriks pembobot $\boldsymbol{W}_{\text {pre }}^{*}, \boldsymbol{W}_{\text {post }}^{*}$, dan $\boldsymbol{W}_{\text {multi }}^{*}$. Setelah diperoleh matriks pembobot, maka selanjutnya dilakukan pemodelan regresi linier antara $Z_{t}$ dengan bobot masing-masing kondisi tanpa konstan. Berikut tiga model regresi linier yang terbentuk beserta estimasi parameternya:

$$
\begin{aligned}
& \widehat{\boldsymbol{Z}}_{\text {pre }}=\hat{\beta} \boldsymbol{W}_{\text {pre }}^{*}=-1992,4615 \boldsymbol{W}_{\text {pre }}^{*} \\
& \widehat{\boldsymbol{Z}}_{\text {post }}=\hat{\beta} \boldsymbol{W}_{\text {post }}^{*}=-2256,2105 \boldsymbol{W}_{\text {post }}^{*} \\
& \widehat{\boldsymbol{Z}}_{\text {multi }}=\hat{\beta} \boldsymbol{W}_{\text {multi }}^{*}=-1992,4615 \boldsymbol{W}_{\text {multi }}^{*}
\end{aligned}
$$

Model regresi linier untuk kondisi pre_holiday dan multiple punya nilai parameter yang sama, hal ini dikarenakan kondisi pre_holiday dan multiple pada kasus hari raya Idul 
Fitri pada tahun 2013 sampai 2017 mempunyai bobot yang sama, maka untuk analisis selanjutnya digunakan model regresi linier untuk kondisi pre_holiday dan post_holiday. Pada taraf signifikansi 5\%, dapat disimpulkan bahwa model regresi linier pada kondisi pre_holiday dan post_holiday memiliki pengaruh yang signifikan dan residualnya tidak memenuhi asumsi white noise karena semua nilai $p_{\text {value }}<\alpha$.

Selanjutnya melakukan pemodelan regARIMA dari residual $\left(N_{t}\right)$ pada model regresi linier untuk kondisi pre_holiday dan post_holiday. Pada uji stasioneritas dalam varian diperoleh nilai lambda untuk kondisi pre_holiday dan post_holiday sebesar 0,9999. Nilai tersebut mendekati satu sehingga dapat disimpulkan bahwa $N_{t}$ dari kondisi pre_holiday dan post_holiday telah stasioner dalam varian. Pada uji Dickey-Fuller dengan taraf signifikansi 5\%, dapat disimpulkan bahwa data $N_{t}$ untuk kondisi pre_holiday dan post_holiday tidak stasioner dalam mean. Selanjutnya dilakukan pembedaan pada data $N_{t}$ kondisi pre_holiday dan post_holiday. Setelah dilakukan pembedaan derajat 1, dapat disimpulkan bahwa pada data residual $\left(N_{t}\right)$ untuk kondisi pre_holiday dan post_holiday sudah stasioner dalam mean.

Selanjutnya identifikasi model regARIMA menggunakan plot ACF dan PACF untuk kondisi pre_holiday dan post_holiday.
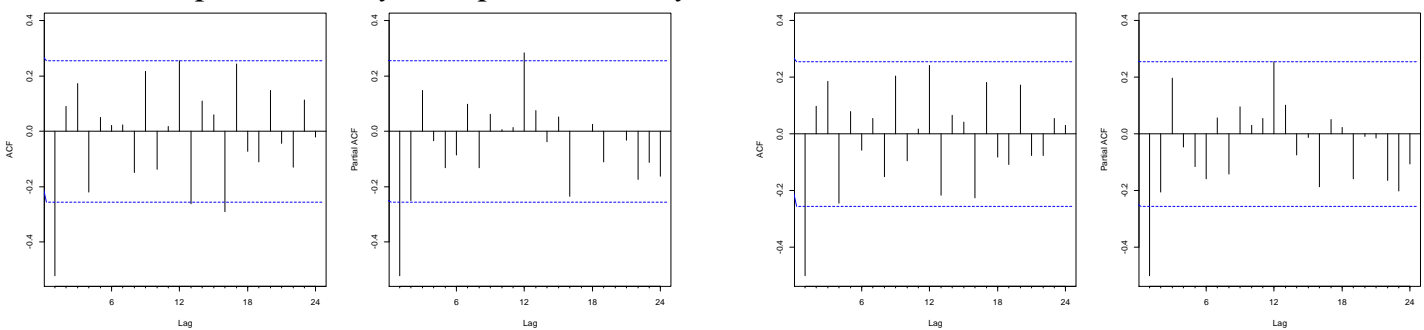

Gambar 2. Plot ACF dan PACF Kondisi pre_holiday dan post_holiday

Model regARIMA yang mungkin untuk kondisi pre_holiday adalah RegARIMA $(1,1,0)(1,0,0) 12$, RegARIMA $(1,1,0)(0,0,1) 12$, RegARIMA $(1,1,0)(1,0,1) 12$, RegARIMA $(0,1,1)(1,0,0) 12$, RegARIMA $(0,1,1)(0,0,1) 12$, RegARIMA $(0,1,1)(1,0,1) 12$, RegARIMA $(1,1,1) \quad(1,0,0) 12, \quad$ RegARIMA $\quad(1,1,1) \quad(0,0,1) 12, \quad$ RegARIMA $\quad(1,1,1) \quad(1,0,1) 12$, RegARIMA(1,1,0), RegARIMA(0,1,1), dan RegARIMA(1,1,1). Model regARIMA yang mungkin untuk kondisi pre_holiday adalah RegARIMA $(1,1,0)(1,0,0)^{12}$, RegARIMA $(0,1,1)(1,0,0)^{12}, \operatorname{Reg} A R I M A(1,1,1)(1,0,0)^{12}, \operatorname{RegARIMA}(1,1,0), \operatorname{RegARIMA}(0,1,1)$, dan $\operatorname{RegARIMA}(1,1,1)$.

Setelah diperoleh beberapa model regARIMA, maka selanjutnya dilakukan estimasi dan uji signifikansi terhadap setiap parameter yang ada pada model regARIMA yang telah diduga. Pada taraf signifikansi 5\%, model yang seluruh parameternya signifikan untuk kondisi pre_holiday model yang signifikan adalah regARIMA $(1,1,0)(1,0,0)^{12}$, regARIMA $(1,1,0)(0,0,1)^{12}$, regARIMA $(0,1,1)(1,0,0)^{12}$, regARIMA $(0,1,1)(0,0,1)^{12}$, regARIMA $(1,1,0)$, dan regARIMA $(0,1,1)$, sedangkan untuk kondisi post_holiday model yang signifikan adalah regARIMA $(1,1,0)$ dan regARIMA $(0,1,1)$.

Selanjutnya uji white noise residual, normalitas residual, dan homoskedastisitas residual dari model-model yang parameternya signifikan, untuk kondisi pre_holiday model regARIMA $(1,1,0)(1,0,0)^{12}$, regARIMA $(1,1,0)(0,0,1)^{12}$, regARIMA $(0,1,1)(1,0,0)^{12}$, regARIMA $(0,1,1)(0,0,1)^{12}$, dan regARIMA $(0,1,1)$ dan untuk kondisi post_holiday model regARIMA $(1,1,0)$ dan regARIMA $(0,1,1)$ residualnya memenuhi asumsi white noise, normalitas, dan homoskedastisitas.

Pemilihan model terbaik pada penelitian ini menggunakan nilai AIC sebagai pembanding, dipilih model yang memiliki nilai AIC terkecil sebagai model terbaik. RegARIMA $(1,1,0)$ pada kondisi post_holiday merupakan model terbaik karena memiliki 
nilai AIC terkecil dibandingkan dengan model regARIMA yang lainnya. Diperoleh model regARIMA $(1,1,0)$ sebagai berikut:

$$
N_{t}=\left(1+\phi_{1}\right) N_{t-1}-\phi_{1} N_{t-2}+a_{t}
$$

Diperoleh model X-13-ARIMA-SEATS $(1,1,0)$ sebagai berikut:

$$
\begin{gathered}
Z_{t}=-2256,2105 W_{\text {post }_{t}}^{*}+\left(1+\phi_{1}\right)\left(Z_{t-1}+2256,2105 W_{\text {post }_{t-1}}^{*}\right)- \\
\phi_{1}\left(Z_{t-2}+2256,2105 W_{\text {post }_{t-2}}^{*}\right)+a_{t}
\end{gathered}
$$

Data residual $\left(N_{t}\right)$ dari model regresi linier pada kondisi post_holiday diperluas dengan cara forecasting dan backcasting dari model regARIMA yang terpilih, diperoleh data perluasan $O_{t}{ }^{(1)}$ yang akan digunakan dalam proses dekomposisi X-12-ARIMA. Dari proses dekomposisi X-12-ARIMA diperoleh data komponen $S A_{t}{ }^{(2)}, C T_{t}{ }^{(3)}$, dan $I_{t}{ }^{(3)}$. Data komponen $S A_{t}{ }^{(2)}$ digunakan untuk pengujian hasil dekomposisi akhir, yaitu uji bulan yang berdekatan dengan nilai rata-rata rasio sebesar 97,74\% dan uji bulan Januari dengan nilai rata-rata rasio sebesar 102,64\%, maka dapat disimpulkan bahwa dekomposisi untuk penghilangan musiman (seasonal adjustment) tersebut berhasil. Diperoleh peramalan pada tahun 2018 sebagai berikut:

Tabel 2. Data Peramalan Akhir

\begin{tabular}{ccc}
\hline Waktu & Peramalan & Aktual \\
\hline Januari 2018 & 13680,6679 & 13245 \\
Februari 2018 & 13242,1413 & 12767 \\
Maret 2018 & 13722,4210 & 14268 \\
April 2018 & 13624,6600 & 13344 \\
Mei 2018 & 17758,2113 & 14596 \\
Juni 2018 & 14845,4052 & 11351 \\
Juli 2018 & 13145,5246 & \\
Agustus 2018 & 14085,0014 & \\
September 2018 & 13525,9012 & \\
Oktober 2018 & 13554,0285 & \\
November 2018 & 13665,8427 & \\
Desember 2018 & 13501,9468 & \\
\hline
\end{tabular}

Berdasarkan Gambar 3, penurunan ekspor nonmigas terbesar terjadi pada Mei 2018 ke Juni 2018 yaitu dari 17758,2113 Juta USD menjadi 14845,4052 Juta USD. Hal ini bertepatan dengan adanya hari raya Idul Fitri yang jatuh pada tanggal 15 Juni 2018. Dapat disimpulkan bahwa peramalan dengan variasi kalender Islam menggunakan X-13-ARIMASEATS berhasil menangani efek moving holiday yang terdapat pada data ekspor nonmigas tahun 2013-2017. Diperoleh nilai MAPE sebesar 0,1090 atau 10,90\% sehingga dapat disimpulkan bahwa kemampuan peramalan baik karena berada diantara 10\%-20\%.

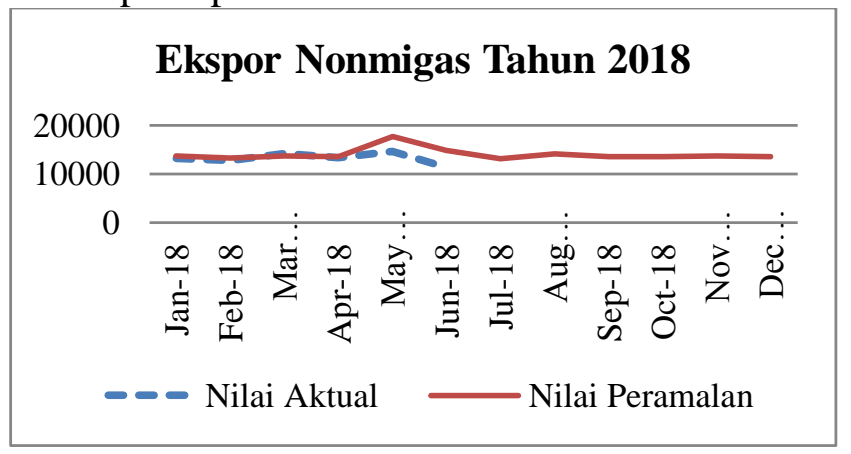

Gambar 3. Plot Nilai Aktual dan Peramalan Ekspor Nonmigas Tahun 2018 


\section{KESIMPULAN}

Berdasarkan analisis dan pembahasan yang telah dilakukan, data ekspor nonmigas pada tahun 2013-2017 diidentifikasi terdapat pola trend, pola musiman dengan periode yang berbeda disetiap tahunnya, dan pola non-stasioner. Model regARIMA mampu menghilangkan efek kalender pada data ekspor nonmigas yang mengandung efek moving holiday dengan model terbaik yaitu regARIMA $(1,1,0)$ pada kondisi post_holiday. Dekomposisi X-12-ARIMA berhasil menangani penyesuaian musiman dari data ekspor nonmigas, karena pada uji bulan yang berdekatan dan uji Januari diperoleh nilai rata-rata dari rasio yang berada diantara 95\%-105\%, yaitu 97,74\% untuk rata-rata dari rasio uji bulan yang berdekatan dan $102,64 \%$ untuk rata-rata dari rasio uji Januari. Peramalan ekspor nonmigas untuk periode Januari 2018 sampai Desember 2018 dilakukan menggunakan metode X-13-ARIMA-SEATS. Hasil peramalan menunjukkan penurunan ekspor nonmigas terbesar terjadi pada Mei 2018 ke Juni 2018 yaitu dari 17758,2113 Juta USD menjadi 14845,4052 Juta USD. Hal ini bertepatan dengan adanya hari raya Idul Fitri yang jatuh pada tanggal 15 Juni 2018. Diperoleh nilai MAPE sebesar 0,1090 atau 10,90\% sehingga dapat disimpulkan bahwa kemampuan peramalan baik karena berada diantara $10 \%-20 \%$.

\section{DAFTAR PUSTAKA}

Bank Indonesia. 2009. Metodologi Neraca Pembayaran Indonesia (NPI).

Bell, W. R. and Hillmer, S. C. 1983. Modeling Time Series With Calendar Variation. Journal of Bussiness and Economic Statistic. 526-534.

Biro Pusat Statistik Israel. (2007). Seasonal Adjusment. www.cbs.gov.il/www/publications/tseries/seasonal07/introduction.pdf (diakses pada tanggal 21 Januari 2018).

Lin, J. L. and Liu, T. S. 2002. Modeling Lunar Calendar Holiday Effect in Taiwan. Taiwan Makridakis, S., Wheelwright, S. C. and McGee, V. E. 1995. Metode dan Aplikasi Peramalan Edisi kedua Jilid 1. Jakarta: Erlangga.

Monsell, B. C. 1984. The Substantive Changes in the X-11 Procedure of X-11-ARIMA. Bureau of the Census, Statistical Research Division, SRD Research Report Number Census/SRD/RR-84/10.

National Statistics. 2007. Guide to Seasonal Adjustment with X-12-ARIMA. ONS Methodology and Statistical Development.

Sarhani, M. and Afia, A. E. 2014. An Extension of X-13-ARIMA-SEATS to Forecast Islamic Holidays Effect on Logistic Activities. Journal of IEEE.

Sembiring, R. K. 2003. Analisis Regresi Edisi Kedua. Bandung: ITB.

Shiskins, J., Young, A. H. and Musgrave, J. C. 1967. The X-11 Variant of The Census Method II Seasonal Adjusment. Bureau of The Census, Technical Paper No. 15.

Shuja, N., Lazim, M. A. and Wah, Y. B. 2007. Moving Holiday Effects Adjustment for Malaysian Economic Time Series. Department of Statistics Malaysia. Volume 1, 35-50.

Siaran Pers Kementerian Perdagangan Republik Indonesia. 20 Juli 2017. Kinerja Ekspor Nonmigas Semester I Berikan Sinyal Positif Capaian Target Ekspor 2017. Jakarta.

United States Census Bureau. 2018. A Basic Seasonal Adjustment Glossary. https://www.census.gov/srd/www/x13as/glossary.html (diakses pada 21 Januari 2018)

Wei, W. W. S. 2006. Time Series Analysis: Univariate and Multivariate Methods. New York: Pearson Education Inc. 